\title{
Seasonal biochemical changes in three species of liverwort Plagiochasma of Mandi (Himachal Pradesh), India
}

\author{
Kanchna Devi \\ Department of Botany, Panjab University, Chandigarh-160014, India \\ Sunita Kapila* \\ Department of Botany, Panjab University, Chandigarh-160014, India \\ Anju Rao \\ Department of Botany, Panjab University, Chandigarh-160014, India \\ ${ }^{*}$ Corresponding author. E-mail: sunitakapilapu@gmail.com
}

\section{Article Info}

DOI: 10.31018/jans.v10i4.1854 Received: August 3, 2018

Revised: September 14, 2018

Accepted: October 4, 2018

\section{How to Cite}

Devi, K. et al. (2018). Seasonal biochemical changes in three species of liverwort, Plagiochasma of Himachal Pradesh region, India. Journal of Applied and Natural Science, 10 (4): $1094-1100$ phyll $(0.76 \pm 0.005 \mathrm{mg} / \mathrm{g}$ fw in $P$. appendiculatum, $0.69 \pm 0.005 \mathrm{mg} / \mathrm{g} \mathrm{fw}$ in $P$. articulatum and $1.2 \pm 0.006 \mathrm{mg} / \mathrm{g}$ fw in $P$. intermedium ) were observed towards the end of the growing season (January-March period of collection), whereas the content of protein $(23.46 \pm 0.14$ $\mathrm{mg} / \mathrm{g} \mathrm{fw}$ in $P$. appendiculatum, $23.33 \pm 0.71 \mathrm{mg} / \mathrm{g} \mathrm{fw}$ in $P$. articulatum and $22.99 \pm 0.27 \mathrm{mg} / \mathrm{g}$ $\mathrm{fw}$ in $P$. intermedium) was maximum during winter (October-December) and that of free amino acids $(37.48 \pm 1.05 \mathrm{mg} / \mathrm{g} \mathrm{fw}$ in $P$. appendiculatum, $70.9 \pm 0.91 \mathrm{mg} / \mathrm{g} \mathrm{fw}$ in $P$. articulatum and $25.13 \pm 0.31 \mathrm{mg} / \mathrm{g} \mathrm{fw}$ in $P$. intermedium) in the rainy season (July-September). On the other hand, the activities of enzymes that breakdown the carbohydrates into simple sugars were recorded least towards the end of the favourable period of their growth. The activity of protease was maximum in the rainy season (July-September) and minimum in the winter season (October-December). This study concluded that the seasonal changes in Plagiochasma induced alterations in the biochemical compounds and in the activities of related enzymes that may be responsible for the adaptation of these plants in their natural habitats.

Keywords: Biochemical changes, Liverworts, Plagiochasma appendiculatum, P. articulatum, $P$. intermedium.

\section{INTRODUCTION}

Plagiochasma is a thalloid liverwort belonging to the order Marchantiales under family Aytoniaceae. It comprises nearly 30 species all over the world (Bischler, 1978). In India only 10 species have been reported, viz., $P$. appendiculatum Lehm. et Lindb, $P$. articulatum Kash., P. bicornutum Steph., P. cordatum Lehm. and Lindb, P. cordotii Steph., P. intermedium L. et Gott., P. martensii Steph., P. nepalensis Steph., P. pauriana Udar et Chandra and $P$. quadricornutum Steph. (Parihar et al., 1994), out of which P. appendiculatum grows abundantly throughout the year. Plagiochasma grows in mesic and xeric habitats in all continents (Bischler, 1978; 1979) to an altitude upto $3000-8000 \mathrm{ft}$ from sea level. Generally it prefers calcium rich soil for its growth and development. The genus is characterized by horse-shoe shaped male receptacles and distinctly dorsal sub -sessile to shortly stalked female receptacles.

Plagiochasma articulatum characterized by distinctly articulated thallus and female receptacle at the articulation. Pores were simple, inconspicuous bounded by three series of 7-8 cells each. The thallus of $P$. intermedium is dichotomously branched with large pores bounded by three or four rings of seven to nine cells each and scale appendages constricted at the base.

$P$. appendiculatum is widely distributed and abundantly growing species in different parts of India. This species is differentiated from the other species of Plagiochasma on the basis of broad lobes and the large ventral scale with appendage strongly constricted at the base. Mostly it grows on naked and exposed rocks that represent the xerophytic habitat (Kachroo, 1954). Ethnomedicinally, it is used in the form of a paste by the Gaddi 
Devi, K. et al. / J. Appl. \& Nat. Sci. 10 (4): 1094-1100 (2018)

tribes in Kangra velley for treating skin diseases (Kumar et al., 2000). It can also be used as a biotest for water quality assessment (Ghates and Chapekar, 2000). Singh et al. (2006) studied the antimicrobial, wound healing and antioxidant activity of this liverwort, but no research activities have been carried out concerning physiological and biochemical comparison of seasonal variations of Plagiochasma in India.

Several environmental factors such as drought, salinity, nutrient imbalances and extremes of temperature adversely affect plant growth and development (Hamayun et al., 2010; Shafi et al., 2011; Akça and Samsunlu, 2012; Bakht et al., 2012; Ejaz et al., 2012). The altitude also plays an important role in this connection, because it is associated with light intensity, air temperature, ozone density, wind exposure, soil fertility etc. At high altitudes, plants are exposed to higher light intensities and lower mean temperatures. Light intensity changes with the seasons also and bryophytes experience different photoperiods. The plants develop mechanisms to prevent the damage caused by photodestruction, freezing and chilling.

The study is aimed to study seasonal changes in various biochemical parameters in the three species of Plagiochasma.

\section{MATERIALS AND METHODS}

Sample collection: Plant materials were collected from different localities of district Mandi (Himachal Pradesh). The study areas were surveyed during different seasons. Plagiochasma was found growing from July to next March, whereas not found during April to June. To study the seasonal variation, the collection period was divided into three seasons relevant to bryophyte life history (Kapila et al., 2014): July-September (rainy season), October-December (winter season) and January-March (end of the growing season). During different seasons, the samples were collected from the study sites, brought to the laboratory, identified and worked out. The voucher specimens are deposited in herbarium, Department of Botany, Panjab University, Chandigarh for future reference. Their month of collection, locality, altitude, substratum and herbarium reference number (PAN) are given in Table 1. The range of the temperature and rainfall during the three seasons are given in Table 2 .

Extracts were made from the tips of vigorously growing healthy plants. The thallus was washed with distilled water and dried in the folds of sterilized blotting paper. The dried $500 \mathrm{mg}$ plant material was homogenized in $10 \mathrm{ml}$ of solvent (distilled water used for the carbohydrates, proteins, $\alpha$ amylase, $\beta$-amylase, invertase, protease, $80 \%$ ethanol used for total free amino acid and $80 \%$ acetone used for chlorophyll and carotenoids) the as per the methods followed for various parame- ters. The suspension was centrifuged at $3000 \mathrm{rpm}$ for 20 minutes at $4^{0} \mathrm{C}$. The supernatant obtained after centrifugation was immediately used for estimation of carbohydrates, proteins, free amino acids, chlorophyll, carotenoids and to study the activities of $\alpha$-amylase, $\beta$-amylase, invertase and protease.

Determination of physiochemical parameters: Total water soluble carbohydrates were estimated by Anthrone method of Yemm and Willis (1954) with glucose as standard. The estimation of total proteins was done by the method of Lowry et al. (1951) using bovine serum albumin as the standard. The concentration of free amino acids was measured by the method of Lee and Takahashi (1966) using ninhydrin reagent and glycine as standard.

The activity of $\alpha$-amylase was measured by the method of Muentz (1977) and the activity of $\beta$ amylase was determined by Bernfeld (1951). The activity of invertase was assayed by the method of Sumner (1935) and the activity of protease was measured according to the method given by $\mathrm{Ba}$ sha and Beevers (1975).

The contents of Chlorophyll a, Chlorophyll b and Carotenoids were estimated by Lichtenthaler and Wellburn (1983)

Statistical analysis: Values were obtained in triplicates and represented as mean \pm SE (standard error). Data from three replicates were subjected to analysis of variance using SPSS for all statistical analyses. Differences between means at $5 \%$ $(P<0.05)$ level were considered as significant.

\section{RESULTS}

The results of this study revealed significant variation $(p<0.05)$ in all the studied parameters in the three species of Plagiochasma during different seasons. In all the species, the concentration of total water soluble carbohydrates was observed markedly higher towards the end of the growing season, lower in the winter season and the lowest in the rainy season. Among the three species of Plagiochasma, $P$. articulatum showed lowest content of total carbohydrates $(5.91 \pm 0.26 \mathrm{mg} / \mathrm{g} \mathrm{fw}$ in rainy season, $14.6 \pm 1.08 \mathrm{mg} / \mathrm{g} \mathrm{fw}$ in winter season and $21.26 \pm 0.09 \mathrm{mg} / \mathrm{g} \mathrm{fw}$ at the end of the growing season), whereas $P$. appendiculatum showed the highest content $(19.95 \pm 1.92 \mathrm{mg} / \mathrm{g} \mathrm{fw}$ in rainy season, $33.44 \pm 1.75 \mathrm{mg} / \mathrm{g} \mathrm{fw}$ in winter season and $70.83 \pm 2.54 \mathrm{mg} / \mathrm{g} \mathrm{fw}$ in the end of the growing season ) in all the three seasons relevant to bryophyte life history (Fig. 1). The seasonal variations in the activities of the enzymes- $\alpha$-amylase, $\beta$ amylase and invertase that are associated with the breakdown of carbohydrates was also studied in all the species. The inverse seasonal pattern was observed in the both $\alpha$ - as well as $\beta$ amylases i.e. lowest activity towards the end of the growing season in $P$. appendiculatum and $P$. 
Devi, K. et al. / J. Appl. \& Nat. Sci. 10 (4): 1094-1100 (2018)

Table 1. Names of studied taxa, months of collection, locality, altitude, substratum and herbarium reference number.

\begin{tabular}{llll}
\hline Name of taxa & $\begin{array}{l}\text { Month of collection, locality } \\
\text { and altitude }\end{array}$ & Substratum & $\begin{array}{l}\text { Herbarium } \\
\text { ence no. }\end{array}$ \\
\hline $\begin{array}{l}\text { Plagiochasma appendiculatum } \\
\text { Lehm. et Lindenb. }\end{array}$ & $\begin{array}{l}\text { August, Mandi; } 750 \mathrm{~m} \\
\text { October, Mandi; } 750 \mathrm{~m} ; \\
\text { January, Mandi; } 750 \mathrm{~m}\end{array}$ & $\begin{array}{l}\text { Wet soil on stony } \\
\text { wall }\end{array}$ & PAN 6105 \\
Plagiochasma articulatum Kash. & $\begin{array}{l}\text { August, Mandi; } 911 \mathrm{~m} \\
\text { October, Mandi; } 911 \mathrm{~m} \\
\text { January, Mandi; } 911 \mathrm{~m}\end{array}$ & On wet soil & PAN 6106 \\
$\begin{array}{l}\text { Plagiochasma intermedium Lin- } \\
\text { denb. et Gottsche }\end{array}$ & $\begin{array}{l}\text { August, Mandi; } 911 \mathrm{~m} \\
\text { October, Mandi; } 911 \mathrm{~m} \\
\text { January, Mandi; } 911 \mathrm{~m}\end{array}$ & On wet soil & PAN 6107 \\
\hline
\end{tabular}

Table 2. Range of temperature and rainfall during the three periods of collection.

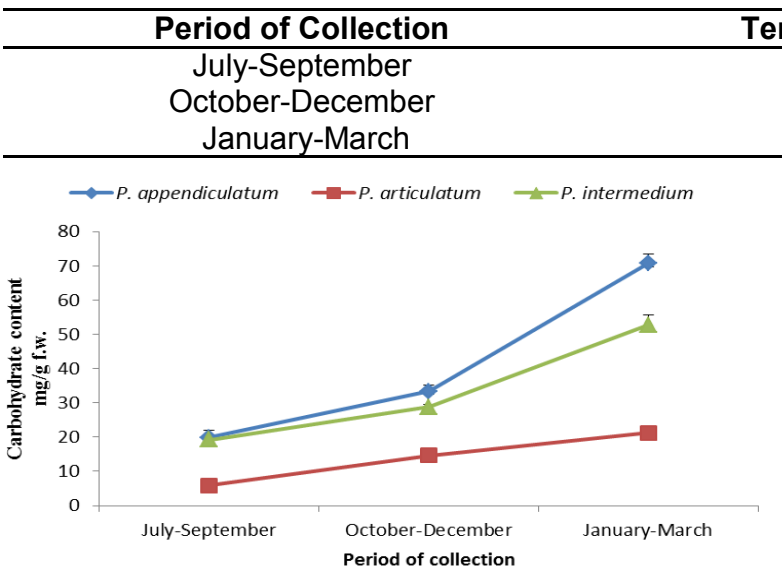

Fig. 1. Variations in carbohydrate content of three species of liverwort Plagiochasma in different periods of collection.

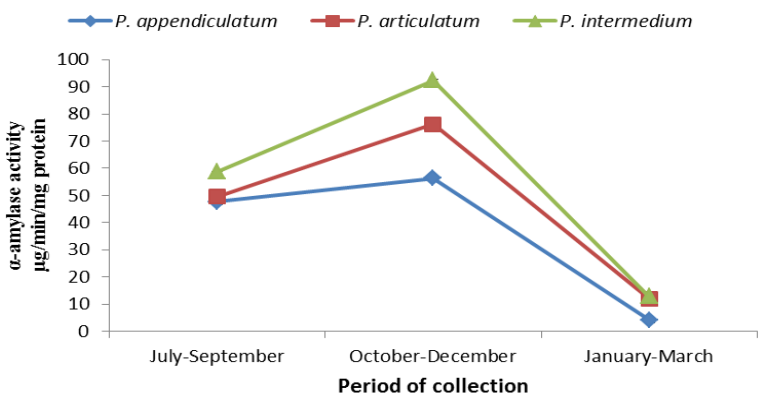

Fig. 2. Variations in specific activity of $\alpha$-amylase of three species of liverwort Plagiochasma in different periods of collection.

intermedium and highest in the winter season in all the three studied species (Fig. 2,3). The activity of invertase however, was observed to be lowest at the end of the growing season in $P$. appendiculatum $(0.3 \pm 0.03 \mu \mathrm{g} / \mathrm{min} / \mathrm{mg}$ protein $)$ and $P$. articulatum $(1.34 \pm 0.12 \mu \mathrm{g} / \mathrm{min} / \mathrm{mg}$ protein) and highest in the rainy season $(12.26 \pm 043 \mu \mathrm{g} / \mathrm{min} / \mathrm{mg}$ protein in $P$. appendiculatum, $7.46 \pm 0.21 \mu \mathrm{g} / \mathrm{min} / \mathrm{mg}$ protein in $P$. articulatum and $8.33 \pm 0.06 \mu \mathrm{g} / \mathrm{min} / \mathrm{mg}$ protein in $P$. intermedium) (Fig. 4).

The protein content in all the three species was found to be highest in the October-December (winter) period of collection, whereas it was lowest

\begin{tabular}{cc} 
Rainfall $(\mathbf{m m})$ \\
\hline $25.5-25.3$ & $240-130$ \\
$23.1-17.4$ & $25-10$ \\
$16.8-21$ & $30-22$ \\
\hline
\end{tabular}

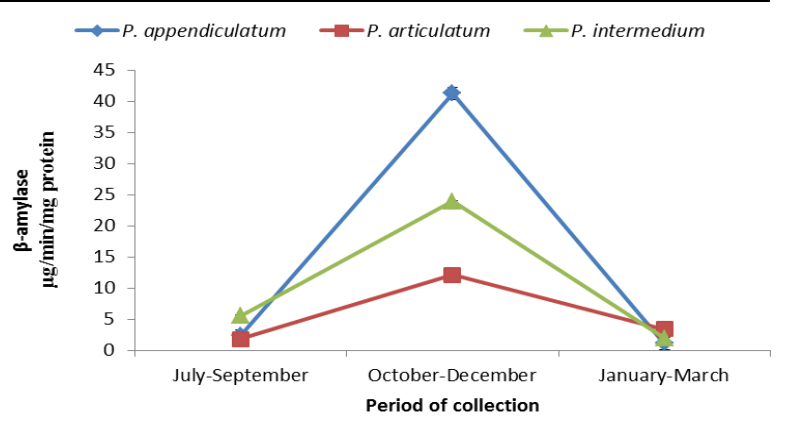

Fig. 3. Variations in specific activity of $\beta$-amylase of three species of liverwort Plagiochasma in different periods of collection.

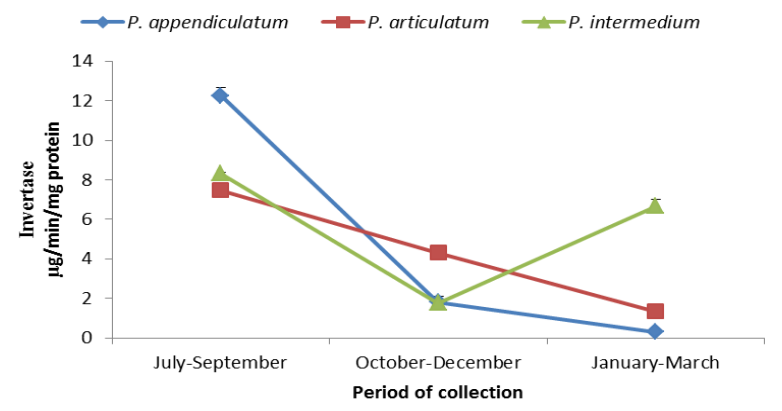

Fig. 4. Variations in specific activity of invertase of three species of liverwort Plagiochasma in different periods of collection.

in $P$. appendiculatum and $P$. articulatum during July-September (rainy) period of collection (Fig. 5). The activity of protease that breaks down the protein into amino acids was at the peak in the rainy season $(48.29 \pm 0.69 \mu \mathrm{g} / \mathrm{hr} / \mathrm{mg}$ protein in $P$. appendiculatum, $46.83 \pm 0.2 \mu \mathrm{g} / \mathrm{hr} / \mathrm{mg}$ protein in $P$. articulatum, $50.3 \pm 0.62 \mu \mathrm{g} / \mathrm{hr} / \mathrm{mg}$ protein in $P$. intermedium) and the minimum $(7.86 \pm 0.22 \mu \mathrm{g} / \mathrm{hr} / \mathrm{mg}$ protein in $P$. appendiculatum $9.3 \pm 0.28 \mu \mathrm{g} / \mathrm{hr} / \mathrm{mg}$ protein in $P$. articulatum and $17.39 \pm 0.38 \mu \mathrm{g} / \mathrm{hr} / \mathrm{mg}$ protein in $P$. intermedium) in the winter season (Fig. 6). The concentration of free amino acids was significantly higher in the rainy season and almost similar in the 
Devi, K. et al. / J. Appl. \& Nat. Sci. 10 (4): 1094-1100 (2018)

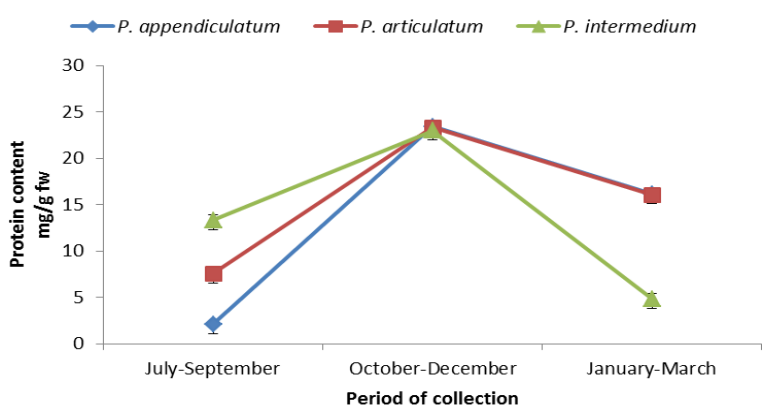

Fig. 5. Variations in protein content of three species of liverwort Plagiochasma in different periods of collection.

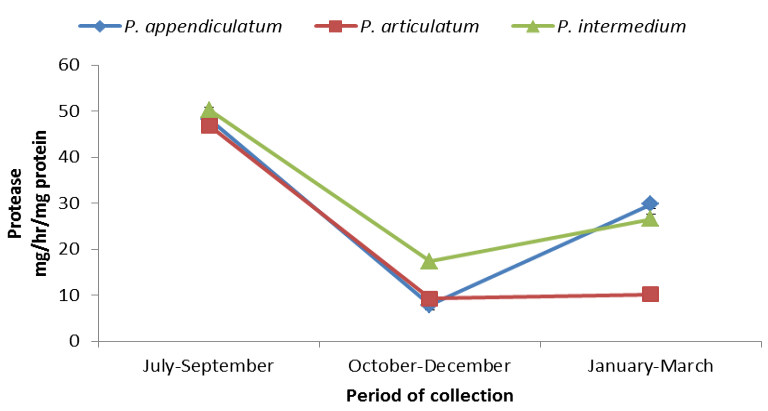

Fig. 6. Variations in specific activity of protease of three species of liverwort Plagiochasma in different periods of collection.

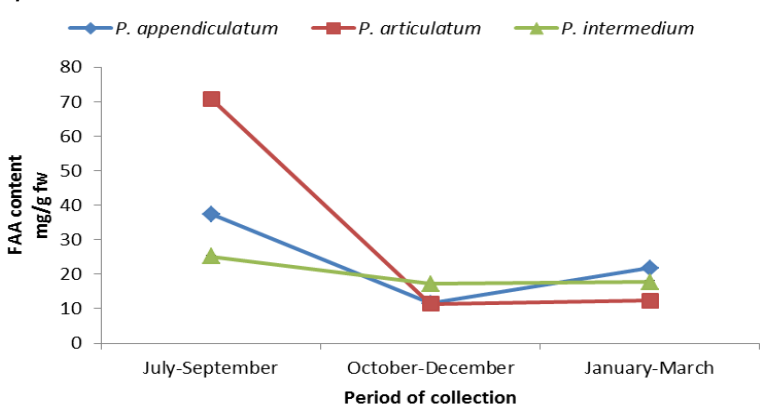

Fig. 7. Variations in free amino acids content of three species of liverwort Plagiochasma in different periods of collection.

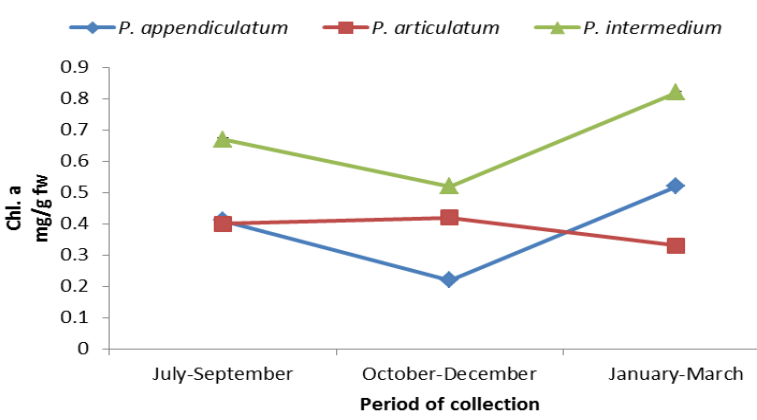

Fig. 8. Variations in chlorophyll a content of three species of liverwort Plagiochasma in different periods of collection.

winter as well as at the end of the growing season in $P$. articulatum and $P$. intermedium (Fig. 7).

$\mathrm{Chl}$. $a$ is higher than Chl. $b$ in all the three species of Plagiochasma in all the three seasons except in

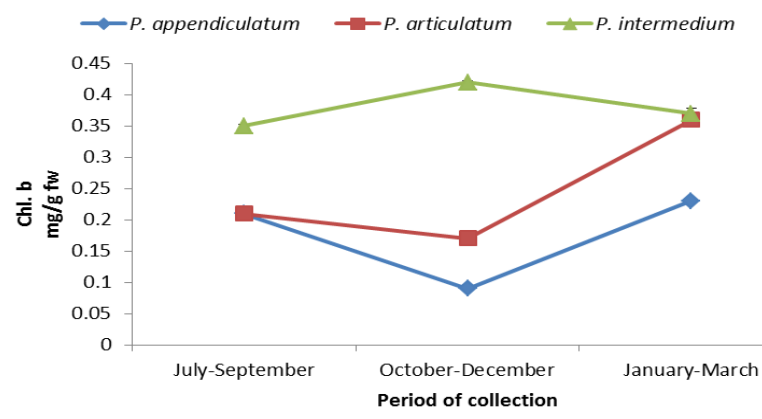

Fig. 9. Variations in chlorophyll $b$ content of three species of liverwort Plagiochasma in different periods of collection.

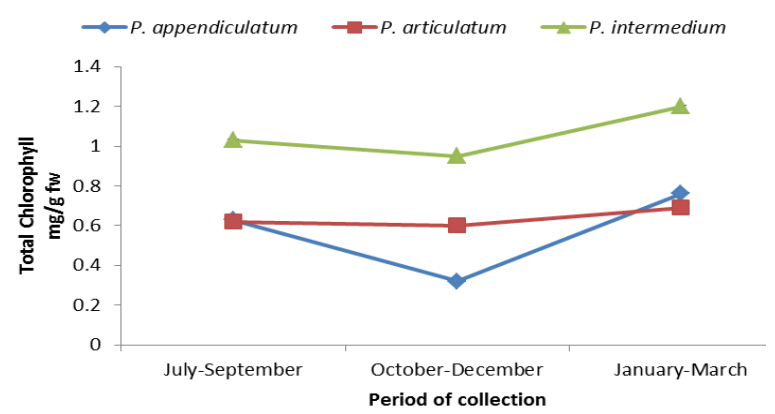

Fig. 10. Variations in total chlorophyll content of three species of liverwort Plagiochasma in different periods of collection.

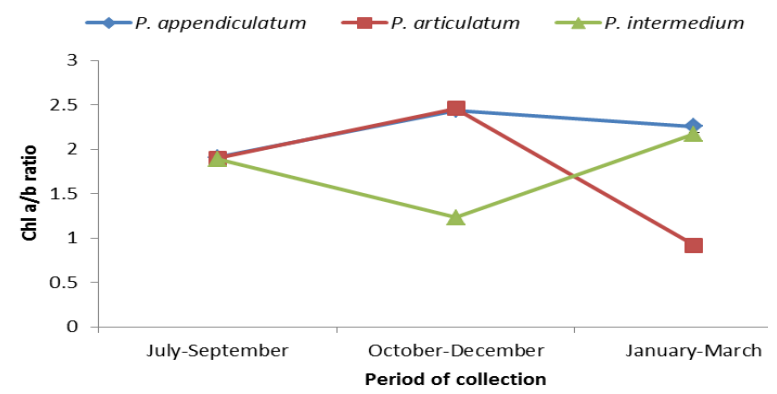

Fig. 11. Variations in chlorophyll $a / b$ ratio of three species of liverwort Plagiochasma in different periods of collection.

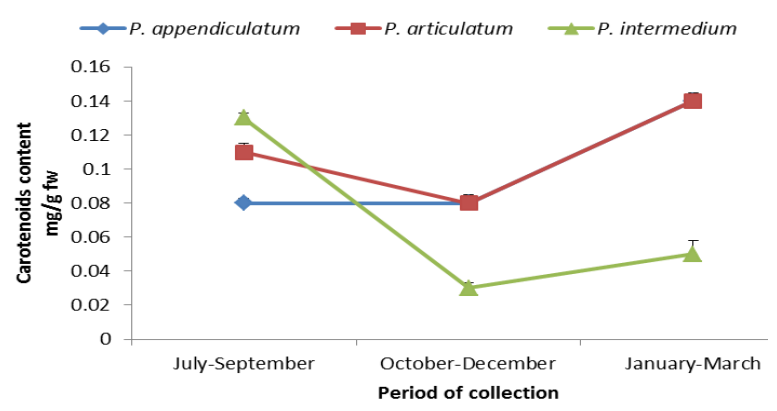

Fig. 12. Variations in carotenoids content of three species of liverwort Plagiochasma in different periods of collection.

$P$. articulatum at the end of the growing season (Fig. 8, 9). The contents of Chlorophyll a, Chlorophyll $b$ and total Chlorophyll were found to be highest in $P$. intermedium than the other two spe- 
cies of Plagiochasma in all the three seasons relevant to bryophyte life history. The maximum chlorophyll content was recorded towards the end of the growing season $(0.76 \pm 0.005 \mathrm{mg} / \mathrm{g}$ fw in $P$. appendiculatum, $0.69 \pm 0.001 \mathrm{mg} / \mathrm{g} \mathrm{fw}$ in $P$. articulatum and $1.2 \pm 0.006 \mathrm{mg} / \mathrm{g}$ fw in $P$. intermedium) and minimum in the winter season $(0.32 \pm 0.008$ $\mathrm{mg} / \mathrm{g} \mathrm{fw}$ in $P$. appendiculatum, $0.6 \pm 0.001 \mathrm{mg} / \mathrm{g} \mathrm{fw}$ in $P$. articulatum and $0.95 \pm 0.003 \mathrm{mg} / \mathrm{g}$ in $P$. intermedium) (Fig. 10). At the end of the growing season, two species of Plagiochasma i.e. P. appendiculatum $(2.26 \pm 0.01)$ and $P$. intermedium $(2.17 \pm 0.02)$ showed the highest chlorophyll $a / b$ ratio, whereas $P$. articulatum showed highest ratio $(2.46 \pm 0.06)$ in the winter season (Fig. 11). In $P$. appendiculatum $(0.08 \pm 0.003 \mathrm{mg} / \mathrm{g} \mathrm{fw}$ in JulySeptember period of collection, $0.08 \pm 0.005 \mathrm{mg} / \mathrm{g}$ $\mathrm{fw}$ in October-December period of collection and $0.14 \pm 0.005 \mathrm{mg} / \mathrm{g}$ in January-March period of collection) as well as $P$. articulatum $(0.11 \pm 0.005 \mathrm{mg} /$ $\mathrm{g} \mathrm{fw}$ in July-September period of collection, $0.08 \pm 0.003 \mathrm{mg} / \mathrm{g} \mathrm{fw}$ in October-December period of collection and $0.14 \pm 0.003 \mathrm{mg} / \mathrm{g}$ in JanuaryMarch period of collection), carotenoid content was almost the same, whereas it significantly varied in $P$. intermedium $(0.13 \pm 0.003 \mathrm{mg} / \mathrm{g}$ fw in JulySeptember period of collection, $0.03 \pm 0.003 \mathrm{mg} / \mathrm{g}$ $\mathrm{fw}$ in October-December period of collection and $0.05 \pm 0.008 \mathrm{mg} / \mathrm{g}$ in January-March period of collection) (Fig. 12).

\section{DISCUSSION}

The higher concentration of carbohydrates in all the three taxa of Plagiochasma towards the end of the growing season is similar to our previous reports on Marchantia and Dumortiera (Kapila and Dhawan, 2000; Kapila et al., 2014). Melick and Seppelt (1994) studied seasonal changes in the soluble carbohydrate levels of the Antarctic bryophytes in 14-month period and revealed little seasonal change in the soluble carbohydrates level which might be due to the extreme climate and rapid temperature fluctuations in the Antarctic environment. In higher plants, stored water soluble carbohydrates provide energy for regrowth after defoliation and also for recovery after drought and persistency during winter when demand of energy cannot be met by photosynthesis (Humphreys, 1994). Higher accumulation of carbohydrates during the end of the growing season may be due to the translocation of non-structural carbohydrates from senescing plants and higher rates of photosynthesis at the beginning of the dry season (Newell et al., 2002). Total chlorophyll content responsible for higher rate of photosynthesis was also found to be higher during the end of the growing season, leading to storage of carbohydrates to be utilized later when the thalli regenerate after dry period.

The activities of the enzymes associated with the breakdown of carbohydrates ( $\alpha$-amylase, $\beta$ amylase and invertase) were also studied during the three seasons. The $\alpha$-amylase catalyses the initial step in hydrolysis of large alpha linked polysaccharides such as starch to a mixture of smaller oligosaccharides consisting of maltose and maltotriose. The low activity of $\alpha$-amylase contributes to the higher accumulation of carbohydrates towards the end of the favourable period of growth. The presently observed decline in the activity of $\alpha$ amylase even during rainy season suggests that the seasonal changes interfere with vital metabolic processes in the liverworts. Udar and Chandra (1960a, 1960b) reported more amylase activity in male plants of Riccia discolor than in female plants.

The $\beta$-amylase is another form of amylase that catalyses the hydrolysis of the second $\alpha-1,4$ glycosidic bond into maltose. It is widely distributed in higher plants and micro-organisms. During the ripening of fruits, it breaks starch into maltose, resulting into its sweet flavor. It also plays a vital role in the germination of cereal seeds (Zieglar, 1999). The end of the growing season showed lowest activity of $\beta$-amylase (except Plagiochasma articulatum) that may contribute a role in the carbohydrate storage.

The increased activity of $\alpha$ - and $\beta$-amylase during the winter season indicates the accumulation of maltose in the cytoplasm. The $\beta$-amylase activity is reported to increase in response to heat stress (Dreier et al., 1995) as well as cold stress (Nielsen et al., 1997).

Invertase is involved in the hydrolysis of sucrose into glucose and fructose. Osmotic pressure of the cells is influenced by the breakdown of sucrose into glucose and fructose that help in cell elongation and growth (Sturm, 1999). In plants, the invertase helps in metabolism, osmoregulation, development and defence mechanism, whereas in humans it acts as an antioxidant, an antiseptic and as immune booster (Kulshrestha et al., 2013). Highest activity of this enzyme in the rainy season indicates the breakdown of sucrose for various metabolic processes during luxuriant growth of these plants. Towards the end of the growing season, low specific activity of this enzyme leads to sucrose accumulation. Sucrose plays an important role in desiccation tolerance of mosses (Smirnoff, 1992). Presently observed low activity of invertase in unfavorable period of growth resulting in accumulation of sucrose enables the plants to tolerate drought conditions.

Proteins are linear, large, complex molecules made up of 20 different amino acids, which are linked by covalent peptide bonds to form polypeptide chain (Chimankar et al., 2011). Protein content is an important tool for the evaluation of physiological standards (Diana, 1982). Low temperature results in the synthesis of proteins 
(Mohapatra et al., 1987; Hughes and Dunn, 1996; Dionne et al., 2001; Liu et al., 2005; Koc et al., 2010). This may be the reason of highest protein content in the winter season in all the presently studied taxa. The possible reasons for the decreased protein content in the July-September period of collection (rainy season) may be the increased protease activity or decreased synthesis of protein in this period.

Protease plays an important role in plant growth, development and defense. It also maintains protein quality and degrades specific set of proteins in response to diverse environmental stimuli. The environmental changes such as light, temperature, drought stress, nutrient supply and pathogens alter the morphology, the metabolism and membrane structure of the cell. The studied taxa showed an inverse relationship between the protease activity and protein concentration in all the seasons.

The maximum content of free amino acids was recorded in the rainy season decreasing towards the end of growing season through the winter season. The increase in the free amino acids in the rainy season could either be due to disruption in protein synthesis or due to partial hydrolysis of proteins. The increase in the free amino acids observed presently is associated with the reduction in proteins at the same time.

The light intensity varies in different seasons and the plants are adapted to respond to these variations. Martin and Churchill (1982) reported remarkable changes in the chlorophyll concentrations and $\mathrm{Chl}$ a/b ratios of mosses grown under different irradiances. The total chlorophyll content was observed highest towards the end of the growing season. This observation is in agreement with our earlier study (Devi et al., 2015) on the thalli of Marchantia and Dumortiera. During summer, the increased irradiance and day length as compared to the rainy and the winter season is responsible for the increase in the chlorophyll level in this period. There have been several reports of maximum concentration of chlorophyll in summer and minimum in winter (Bourdeau, 1959; Gerold, 1959; Linder, 1972; Senser et al., 1975) in conifers also. Melick and Seppelt (1994) recorded the same observations in the Antarctic bryophytes. The seasonal changes in the chlorophyll concentration of the studied liverworts are like those in the higher plants indicating that the adaptations of both the groups of plants are the same in response to the prevailing light conditions in different seasons.

\section{Conclusion}

The results of our experimental work are indicative of the seasonal patterns in the content of the estimated biochemical constituents and activity of related enzymes which in turn explain their func- tional importance in plant growth and metabolism during different times of the year. To summarize, it is concluded that the alterations in biochemical compounds and activities of related enzymes in different seasons are responsible for the adaption of the studied three species of Plagiochasma to their natural habitats.

\section{ACKNOWLEDGEMENTS}

The first author is thankful to the University Grant Commission (UGC-BSR) for the financial assistance in the form of fellowship.

\section{REFERENCES}

1. Akça, Y. and Samsunlu, E. (2012). The effect of salt stress on growth, chlorophyll content, proline and nutrient accumulation, and K/Na ratio in walnut. Pak. J. Bot. 44: 1513-1520.

2. Bakht, J., Khan, M. J., Shafi, M., Khan, M. A. and Sharif, M. (2012). Effect of salinity and ABA application on proline production and yield in wheat genotypes. Pak. J. Bot. 44: 873-878.

3. Basha, S. M. M. and Beevers, L. (1975). The development of proteolytic activity and protein degradation during the germination of Pisum sativum L. Planta. 124: 77-87.

4. Bernfeld, P. (1951). Amylases $\alpha$ and $\beta$. Methods in Enzymology, Academic Press, New York, pp 149158.

5. Bischler, H. (1978). Plagiochasma Lehm. et Lindenb. II. Les taxa europeens et africains Plagiochasma Lehm. and Lindenb. II. European and African taxa]. Reve Bryologique Lichenologique. 44: 223300.

6. Bischler, H. (1979). Plagiochasma Lehm. et Lindenb. III. Les taxad'Asie et oceanie. J. Hatt. Bot. Lab. 45: 25-79.

7. Bourdeau, P. F. (1959). Seasonal variations of the photosynthetic efficiency of evergreen conifers. Ecology. 40: 63-67.

8. Chimankar, O. P., Shriwas, R. and Tabhane, V. A. (2011). Intermolecular interaction studies in some amino acids with aqueous $\mathrm{NaOH}$. J. Chem. Pharm. Res. 3: 587-596.

9. Devi, K., Kapila, S. and Rao, A. (2015). Seasonal variations in the photosynthetic pigments of three species of Marchantiaceae. Int. J. Adv. Pharm. Bio. Chem. 4: 713-718.

10.Diana, J. S. (1982). An experimental analysis of the metabolic rate and food utilization of northern pike. Comp. Biochem. Physiol. 71A: 395-399.

11.Dionne, J., Castonguay, Y., Nadeau, P. and Desjardins, Y. (2001). Amino acid and protein changes during cold acclimation of green-type annual bluegrass (Poa annua L.) ecotypes. Crop Sci. 41: 18621870.

12.Dreier, W., Schnarrenberger, C. and Boerner, T. (1995). Light and stress-dependent enhancement of amylolytic activities in white and green barley leaves: beta-amylases are stress-induced proteins. J. Plant Physiol. 145: 342-348.

13.Ejaz, B., Sajid, Z. A. and Aftab, F. (2012). Effect of exogenous application of ascorbic acid on antioxidant enzyme activities, proline contents and growth parameters of Saccharum spp., hybrid cv. HSF-240 
Devi, K. et al. / J. Appl. \& Nat. Sci. 10 (4): 1094-1100 (2018)

under salt stress. Turk. J. Biol. 36: 630-640.

14.Gerold, H. D. (1959). Seasonal variation of chloroplast pigments and nutrient elements in the needles of geographic races of Scitch Pine. Silvae Gernet. 8: 113-123.

15.Ghates, S. and Chapekar, S. B. (2000). Plagiochasma appendiculatum as a biotest for water quality assessment. Environ. Pollut. 108(2): 173-181.

16. Hamayun, M., Sohn, E. Y., Khan, S. A., Shinwari, Z. K., Khan, A. L. and Lee, I. J. (2010). Silicon alleviates the adverse effects of salinity and drought stress on growth and endogenous plant growth hormones of soybean (Glycine max L.). Pak. J. Bot. 42: 17131722.

17. Hughes, M. A. and Dunn, M. A. (1996). The molecular biology of plant acclimation to low temperature. $J$. Exp. Bot. 47: 291-305.

18. Humphreys, M. O. (1994). Variation in the carbohydrate and protein content of ryegrass: Potential for genetic manipulation. Breeding for quality: Proceeding of the 19th Eucarpia Fodder Crops Section Meeting, Brugge, Belgium, pp 165-172.

19.Kachroo, P. (1954). Morphology of rebouliaceae II. On species of Marria Corda, Asterella Baeuv. and Plagiochasma L. et L. J. Hatt. Bot. Lab. 12: 34-52.

20.Kapila, S. and Dhawan, A. (2000). Preliminary biochemical studies on some west Himalayan bryophytes. Pb. Univ. Res. Bull. 50: 107-113.

21.Kapila, S., Devi, K., Rao, A. and Mahajan, A. (2014). Seasonal variations in carbohydrate, protein, free amino acids and enzyme activities in three species of Marchantiaceae. Lindbergia. 37: 85-89.

22.Koc, E., Islek, C. and Ustun, A. S. (2010). Effect of cold on protein, proline, phenolic compounds and chlorophyll content of two pepper (Capsicum annuum L.) varieties. G.U. J. Sci. 23(1): 1-6.

23.Kulshrestha, S., Tyagi, P., Sindhi, V. and Yadavilli, K. S. (2013). Invertase and its applications - A brief review. J. Pharm. Res. 7(9): 792-797.

24.Kumar, K., Singh, K. K., Asthana, A. K. and Nath, V. (2000). Ethnotherapeutics of bryophyte Plagiochasma appendiculatum among the Gaddi Tribes of Kangra Valley, Himachal Pradesh, India. Pharm. Biol. 38: 353-356.

25.Lee, Y. P. and Takahashi, T. (1966). An improved colorimetric determination of amino acid with the use of ninhydrin. Anal. Biochem. 14: 71-77.

26. Lichtenthaler H. K. and Wellburn, A. R. (1983). Determination of total carotenoids and chlorophylls a and $b$ of leaf extracts in different solvents. Biochem. Soc. Trans. 11: 591-592.

27.Linder, S. (1972). Seasonal variation of pigments in needles. A study of scots pine and Norway spruce grown under different nursery conditions. Stud. For. Suec. 100: 1-37.

28.Liu, M., Shen, X., Yin, W. and Lu, C. (2005). Functional analysis of cold-inducible cDNA clones in the Legume Ammopiptanthus mongolicus. CryoLetters. 26: 213-222.

29.Lowry, O. H., Rosebrough, N. J., Farr, A. L. and
Rendall, R. J. (1951). Protein estimation with folin phenol reagent. J. Biol. Chem. 193: 265-275.

30.Martin, C. E. and Churchill, S. P. (1982). Chlorophyll concentrations and $\mathrm{a} / \mathrm{b}$ ratios in mosses collected from exposed and shaded habitats in Kansas. J. Bryol. 12: 297-304.

31.Melick, D. R. and Seppelt, R. D. (1994). Seasonal investigation of soluble carbohydrate and pigment level in Antarctic bryophytes and lichens. Bryologist. 97: 13-19.

32.Mohapatra, S. S., Poole, R. J. and Dhindsa, R. S. (1987). Cold acclimation, freezing resistance and protein synthesis in alfalfa (Medicago sativa L. cv. Saranac). J. Exp. Bot. 38: 1697-1703.

33.Muentz, K. (1977). The function of the pod for protein storage in seeds of Vicia faba L. 5 isoenzymes of $\alpha$ amylase during pod development of field beans. Phytochemistry. 16: 1491-1494.

34.Newell, E. A., Mulkey, S. S. and Wright, S. J. (2002). Seasonal patterns of carbohydrate storage in four tropical tree species. Oecologia. 131: 333-342.

35.Nielsen, T. H., Deiting, U. and Stitt. M. (1997). A beta -amylase in potato tubers is induced by storage at low temperature. Plant Physiol. 113: 503-510.

36.Parihar, N.S., Lal, B. and Katiyar, N. (1994). Hepaticae and Anthocerotae of India. A New Annotated Checklist Central Book Depot, Allahabad.

37.Senser, M., Schötz, F. and Beck, E. (1975). Seasonal changes in structure and function of spruce chloroplasts. Planta. 126: 1-10.

38.Shafi, M., Bakht, J., Khan, M. J., Khan, M. A. and Raziuddin. (2011). Role of abscisic acid and proline in salinity tolerance of wheat genotypes. Pak. J. Bot. 43: 1111-1118.

39.Singh, M., Govindarajan, R., Nath, V., Rawat, A. K. S. and Mehrotra. S. (2006). Antimicrobial, wound healing and antioxidant activity of Plagiochasma appendiculatum Lehm. et Lind. J. Ethnopharmacol. 107: 67-72.

40.Smirnoff, N. (1992). The carbohydrates of bryophytes in relation to desiccation tolerance. J. Bryol. 17: 185191.

41.Sturm, A. (1999). Invertases. Primary structures, functions and roles in plant development and sucrose partitioning. Plant Physiol. 121: 1-8.

42.Sumner, J. B. (1935). A more specific reagent for the determination of sugar in urine. J. Biol. Chem. 69: 393-395.

43.Udar, R. and Chandra, S. (1960a). Enzymes of Hepaticae. I. A preliminary report. Current Sci. 29: 104105.

44.Udar, R. and Chandra, S. (1960b). Enzymes of Hepaticae. II. On the enzymes in Riccia discolor $\mathrm{L}$. et $\mathrm{L}$. J. Hatt. Bot. Lab. 23: 85-92.

45.Yemm, E. W. and Willis, A. J. (1954). The estimation of carbohydrates in plant extracts by anthrone. Biochem. J. 57: 508-514.

46.Ziegler, P. (1999). Cereal beta-amylases. J. Cereal Sci. 29: 195-204. 